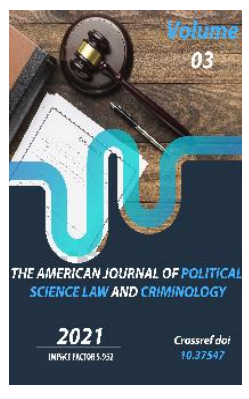

\title{
The Current State Of International Legal Cooperation In The Field Of Labour Migration
}

\author{
Durdonaxon Oybek qizi Murodova \\ "Istiqbolli Avlod" Riam, Uzbekistan
}

Journal Website: https://theamericanjou rnals.com/index.php/ta jpslc

Copyright: Original content from this work may be used under the terms of the creative commons attributes 4.0 licence.

\section{ABSTRACT}

This subject analyses the framework of international law that regulates the flow of people across international borders as regular or irregular migrants. It also equips students to understand the human rights of migrants who live or work in countries outside the state of their nationality.

\section{KEYWORDS}

Migration, cooperation, legal, international, travel passport, nationality, law, regular, irregular, immigrants, immigration.

\section{INTRODUCTION}

Internal migration: moving within a state, country, or continent. External migration: moving to a different state, country, or continent. Emigration: leaving one country to move to another. Immigration: moving into a new country. Return migration: moving back to where you came from.

United Nations Economic Commission for Europe (UNECE), United Nations Development

http://un.org/esa/devaccount/projects/2008/0809A .html
Accounts Strengthening national capacities to improve migration data: maximizing development benefits and minimizing negative impacts"”

There are four major forms of migration: invasion, conquest, colonization and emigration/immigration. Persons moving from their home due to forced displacement (such as a natural disaster or civil disturbance) may 
be described as displaced persons or, if remaining in the home country, internally displaced persons. The following The following can lead to migration:

- Higher employment.

- More wealth.

- Better services.

- Good climate.

- Safer, less crime.

- Political stability.

- More fertile land.

- Lower risk from natural hazards².

Human migration involves the movement of people from one place to another with intentions of settling, permanently or temporarily, at a new location (geographic region). The movement often occurs over long distances and from one country to another, but internal migration (within a single country) is also possible; indeed, this is the dominant form of human migration globally. Migration is often associated with better human capital at both individual and household level, and with better access to migration networks. Age is also important for both work and non-work migration. People may migrate as individuals, in family units or in large groups. There are four major forms of migration: invasion, conquest, colonization and emigration/immigration.

Key differences Between Migrants and Immigrants

Migrant $=$ temporary movement. Immigrant = permanent residency. Migration can occur within the borders of the same country, or cross international borders. Immigration occurs when a person crosses an international

2

https://en.wikipedia.org/wiki/History_of_human_m igration border and becomes a permanent resident in another country

Often censuses and surveys are viewed as sources of the same type - obviously, the predominant way of collecting data is through interviews with respondents. However, some countries with developed population registers have already switched to register-based censuses. They do not require the personal participation of the population in the survey. Information incl. Migration information is collected automatically by integrating data about a person from different registers, in which it represented each person under his unique personal number. Censuses are based on administrative sources. In the overwhelming majority of countries, the census is still traditionally carried out by visiting interviewers on residential premises and polling the population using a special questionnaire ${ }^{3}$. Persons moving from their home due to forced displacement (such as a natural disaster or civil disturbance) may be described as displaced persons or, if remaining in the home country, internally displaced persons. A person who seeks refuge in another country can, if the reason for leaving the home country is political, religious, or another form of persecution, make a formal application to that country where refuge is sought and is then usually described[by whom?] as an asylum seeker. If this application is successful, this person's legal status becomes that of a refugee.

In contemporary times,[when?] migration governance has become closely associated with state sovereignty. States retain the power of deciding on the entry and stay of non-

\footnotetext{
3 During the 2010 round of censuses, out of forty countries in the UNECE region, 27 conducted or are planning to conduct a census using the traditional survey method (see P. Valente, 2010).
} 
nationals because migration directly affects some of the defining elements of a State.

It is rooted in its Fundamental Principles and universal character as well as in its volunteer and community basis. However, patterns and issues associated with migration change over time.

We should, therefore, continually examine our ways of working with and for migrants to ensure that our action remains strong, coherent, and mindful of crosscutting issues. Our policy on migration is a living policy: It will be reviewed and, if necessary, revised as we evaluate its implementation.

Each National Society and the International Federation shall take into account and adopt the following approach on migration.

1. Focus on the needs and vulnerabilities of migrants

2. Include migrants in humanitarian programming

3. Support the aspirations of migrants

4. Recognize the rights of migrants

5. Link assistance, protection and humanitarian advocacy for migrants

6. Build partnerships for migrants

7. Work along the migratory trails

8. Assist migrants in return

9. Respond to the displacement of populations

10. Alleviate migratory pressures on communities of origin

It also provides the means by which certain aliens can become legally naturalized citizens with full rights of citizenship. Immigration law serves as a gatekeeper for the nation's border, determining who may enter, how long they may stay, and when they must leave.
Migrants might be defined by foreign birth, by foreign citizenship, or by their movement into a new country to stay temporarily (sometimes for as little as one month) or to settle for the long-term. ... In some scholarly and everyday usage, people who move internally within national boundaries are called migrants ${ }^{4}$.

Actually, in any countries have protection system and rules of migrants and immigrants. Namely:

- UN Refugee Convention (1951)3

- Immigration and Nationality Act 1952 / 1965.

- Refugee Act (1980)

- Immigration Reform and Control Act (1986)

- American Homecoming Act (1989)

- Immigration Act 1990.

Illegal Immigration Reform and Immigrant Responsibility Act (IIRIRA) (1996)

As well as they are not just a name of books they are the protective shell of migrants and immigrants which can help them when they need to protection and care about them when they are ill.

In addition, how do these rules work in Uzbekistan? How are immigrants and migrants protected in our country?

There are many rules and principles for migrants and immigrants in our country, which survives their interest. In addition, there are many comforts which is made for them and their children.

The follows can be example

\footnotetext{
${ }^{4}$ https://dataguide.migrationobservatory.ox.ac.uk/
} 
The Consultative Council on Labor, Migration and Social Protection of the CIS Member States has been established and operates to:

Develop a policy of reconciliation by providing advice and exchanging views on important issues of mutual interest;

Harmonization of the legislation of the CIS member states and regulation of issues related to labor relations, migration, employment, social protection and labour protection;

Development of proposals on these issues and approval of draft intergovernmental agreements.

As well as that Support social, work in the protection of children affected by migration in Uzbekistan.

The growth of labour migration in Uzbekistan has created new challenges for structures that support vulnerable families. To address migration issues, the Republican Centre for Social Adaptation of Children conducted trainings for social workers on social work practices with children and families affected by migration.

In Uzbekistan, there has long been a discussion about the use of a customs declaration for similar measuring purposes, where the purpose of the trip is indicated and the flows of labour migration can be determined ${ }^{5}$.

These activities are part of a project to identify and protect children abandoned by immigrant parents in four regions of Uzbekistan Bukhara, Fergana, Surkhandarya and Khorezm.

\footnotetext{
${ }^{5}$ International Migration Statistics A Practical Guide for Eastern Europe and Central Asia. UNITED NATIONS 2011
}

The project is implemented by the Women's Committee of Uzbekistan and UNICEF and funded by the European Union.

Prolonged absence of parents from children's daily lives can have a negative impact on their well-being and health," "The aim of the training was to train child care professionals in social work skills to better protect children affected by migration."

To the measures taken to regulate the processes of external labour migration, the conclusion of international agreements on the organized recruitment of citizens for work abroad, the creation of favourable conditions for their safe access to work outside the country however, a large influx of illegal labour migration persists.

The rate of organized employment of citizens abroad, as well as the employment of returnees, remains low.

Further improvement of the system of external labor migration, radical expansion of its organizational forms, ensuring the protection of labor and social rights of citizens leaving the country for work, In order to expand the involvement of returning migrant workers in entrepreneurship and labor, as well as the consistent implementation of the tasks set out in the Action Strategy for the five priority areas of development of the Republic of Uzbekistan in 2017-2021 so many activities was carried out. Of course they are all brilliant example to show how it is important to care and protect migrants and immigrants ${ }^{6}$.

In my these rules can create better life for migrants and immigrants their children as well

${ }^{6}$ https://nbu.uz/en/normative-legal-documents 
The American Journal of Political Science Law and Criminology (ISSN - 2693-0803)

Published: August 31, 2021 | Pages: 28-32

Doi: https://doi.org/10.37547/tajpslc/Volume03Issueo8-06

of course those are all help of smart leader who cares and who is ready to do any good things for his people.

\section{REFERENCES}

1. International Migration Law:

Developing Paradigms and Key

Challenges.

2. Information legal portal.

3. Law.cornel.edu.

4. En.em.wikipedia.orf.

5. http://un.org/esa/devaccount/projects/ 2008/0809A.html.

6. https://en.wikipedia.org/wiki/History_o f_human_migration.

7. During the 2010 round of censuses, out of forty countries in the UNECE region, 27 conducted or are planning to conduct a census using the traditional survey method (see P. Valente, 2010).

8. https://dataguide.migrationobservator y.ox.ac.uk/

9. International Migration Statistics A Practical Guide for Eastern Europe and Central Asia. UNITED NATIONS 2011.

10. https://nbu.uz/en/normative-legaldocuments. 